\title{
Drakk han alkohol?
}

\author{
Norske forskere har funnet ut hvordan man med større sikkerhet \\ kan avdekke hvorvidt alkohol er inntatt før døden.
}

I noen tilfeller dannes alkohol naturlig i kroppen etter at døden har inntrådt, særlig i trafikkulykker der indre organer skades, og i tilfeller der liket blir liggende en stund før nedkjøling. Tidligere har det vært vanskelig å finne ut hvorvidt alkoholen i avdødes kropp er inntatt på forhånd eller dannet etter døden. Men lege og forsker Gudrun Høiseth har studert hvordan to relativt ukjente stoffer, etylglukuronid og etylsulfat, kan være til hjelp. Alkohol omdannes til ulike stoffer, blant annet disse to.

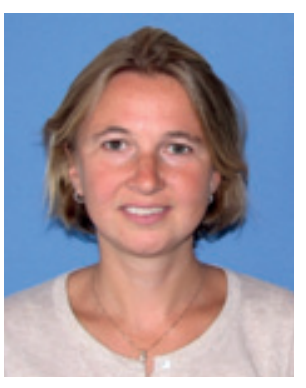

Gudrun Høiseth. Foto Folkehelseinstituttet
- Vi fant at omdanningsproduktene kan brukes for å bekrefte eller avkrefte at vedkommende har drukket alkohol. Dette er svært viktig for eksempel i forsikringssaker, der det er avgjørende hvorvidt føreren eller arbeidstakeren var alkoholpåvirket på ulykkestidspunktet, eller ved barnedødsfall, der funnet kan være avgjørende $i$ en eventuell straffesak, sier Høiseth.

Fastsettelse av tidspunkt for alkoholinntak kan være viktig også i saker som angår levende personer.

- En vanlig forklaring ved for eksempel mistanke om fyllekjøring er at alkoholen ble inntatt etter av kjøringen var avsluttet. Problemet med alkohol er at det omdannes raskt i kroppen. Metabolittene etylglukuronid og etylsulfat derimot, dannes langsomt. Med denne målemetoden kan man med større sikkerhet fastslå når vedkommende hadde drukket, sier Høiseth.

Hun disputerte for ph.d.-graden ved Universitetet i Oslo 20.11. 2009, med avhandlingen Use of ethyl glucuronide and ethyl sulphate in forensic toxicology.

\section{Eline Feiring}

eline.feiring@legeforeningen.no

Tidsskriftet

\section{Ordforklaringer}

Etylglukuronid og etylsulfat: Ikke-oksidative omdanningsprodukter av etanol. Under $0,1 \%$ av inntatt etanol omdannes til disse produktene.

Alkohol (etanol): Inntas som drikke, men kan også dannes i kroppen etter døden.

\section{Liten pumpe kan redde liv}

\author{
Kliniske fors $ø$ k på griser viser at en nyutviklet miniatyrhjertepumpe \\ kan ha potensial til å forbedre behandling av hjertestans, redde flere liv, \\ og hindre hjerneskade hos overlevende.
}

Behandling av hjertestans etter akutt hjerteinfarkt blir stadig bedre: rask hjerte-lungeredning, hjertestarter, blokking av tette hjerteårer og nedkjøling redder mange pasienter. Likevel er det mange som ikke overlever til de kommer til sykehus, hovedsakelig pga. manglende blodsirkulasjon til vitale organer. Blant dem som overlever er hjerneskader et vesentlig problem.

Vegard Tuseth ved Hjerteavdelingen, Haukeland universitetssykehus, har utført kliniske forsøk med griser som viser at en nyutviklet miniatyrhjertepumpe som legges inn via blodårene i lysken, kan ha gunstig effekt på blodsirkulasjon, hjerneskade og $ø$ ke sjansen for vellykket gjenoppliving sammenliknet med manuell resuscitering.

- Forsøkene er utført på griser på rundt $50 \mathrm{~kg}$ som ble påfort hjertestans mens de var bedøvet. Effekten ble målt ved å studere trykket i hovedpulsåre, lunger og kraniet, måle blodgjennomstrømning i hjerne, hjerte og nyrer samt måling av hjernemetabolisme under hjertestans og defibrillering. Vi ser at pumpen kan opprettholde blodgjennomstrømningen til vitale organer uten samtidig hjerte-lunge-redning, sier Tuseth.

Håpet er at behandling med hjertepumpe kan bedre overlevelsen hos pasienter med hjertestans. Tuseth og kollegene skal starte kliniske studier for å kartlegge effekten av denne behandlingen hos pasienter. Han forsvarte avhandlingen Percutaneous left ventricular assist device in cardiac arrestexperimental studies for ph.d.-graden ved Universitetet i Bergen 16.12. 2009.

\section{Anne Forus}

anneforu@online.no

Tidsskriftet

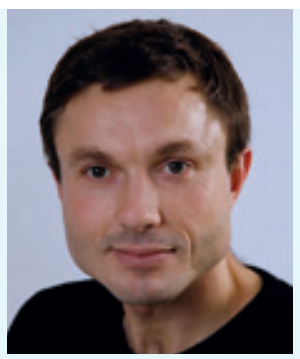

Vegard Tuseth. Foto Anne Sidsel Hedlevær

\section{Ordforklaringer}

Miniatyrhjertepumpe: Pumpen er designet for bruk på mennesker. Grisen har en anatomi og et blodomløp som er ganske likt menneskets, derfor er grisen et egnet forsøksobjekt for disse studiene. Pumpen føres opp til venstre hjertekammer fra lårpulsåren. Denne operasjonen må veiledes ved hjelp av røntgen. Den elektriske pumpen suger 2,5 I blod per minutt ut av venstre hjertekammer og pumper det ut i hovedpulsåren. Studiene viser at pumpen kan bidra til at blodstrømmen til hjerne og hjerte er like god eller bedre sammenliknet med åpen hjertemassasje. Pumpen kan muligens erstatte vanlig hjerte-lungeredning hos enkelte pasienter og kan også redusere behov for adrenalin $\mathrm{i}$ forbindelse med akuttbehandlingen. 